\title{
HYDRAULIC STABILITY OF COASTAL STRUCTURES MADE OF GEOTEXTILE SAND CONTAINERS (GSCS): EFFECT OF ENGINEERING PROPERTIES OF GSCS
}

\author{
Darshana T. Dassanayake ${ }^{1}$ and Hocine Oumeraci ${ }^{1}$
}

\begin{abstract}
Due to their numerous advantages, Geotextile Sand Containers (GSCs /or Geobags) are getting increasingly popular as an alternative to conventional hard (rock / concrete) structures. This study attempts to evaluate the significance of the most important engineering properties and their influence on the hydraulic stability of GSC-structures. The most important engineering properties of GSCs are the mechanical properties of the geotextile material, the sand fill ratio, type of the fill material, the interface friction, etc. In fact most of these properties will affect the deformation of GSCs and the movement of sand inside the container. More importantly, these properties are interrelated. The importance of these aspects has been highlighted in many studies and projects worldwide. However, the knowledge about the influence of the sand fill ratio, the properties of fill material and the interface friction of GSCs on the hydraulic stability of GSC-structure is still very poor. Therefore, a series of experimental investigations were conducted, in order to better understand their effect on the hydraulic stability and to develop a computational tool and simple formulae for the hydraulic stability of different types of GSC-structures subject to different wave conditions. This paper contains some selected findings from these experimental investigations, which were performed at LeichtweissInstitute for Hydraulic Engineering and Water Resources (LWI). Furthermore, the sensitivity of each GSC property on the hydraulic stability and new hydraulic stability nomograms are presented, including the implications for the engineering practice.
\end{abstract}

Keywords: Geotextile Sand Container, coastal structures, hydraulic stability, sand fill ratio, interface friction

\section{INTRODUCTION}

More versatile materials and innovative solutions are required for the design of new, cost effective shore protection structures as well as for the reinforcement of existing threatened coastal barriers and structures, including dune reinforcement and scour protection (Oumeraci and Recio, 2010). Geotextile Sand Containers (GSC) is a low cost, soft and reversible solution for the above problem and it has a history of more than 50 years in hydraulic and marine applications. Coastal structures built with GSCs are obtained by substituting rocks or concrete units with containers made of geotextile and filled with locally available sand (Fig. 1). A range of successful coastal protection structures using GSCs have been constructed in many parts of the world, especially in Australia and Germany (Heerten et al. 2000, Restall et al. 2002, Restall et al. 2004, Saathof et al. 2007, Carley et al. 2011, Wishaw et al. 2011, Bleck and Werth 2012, Werth et al. 2012, ).

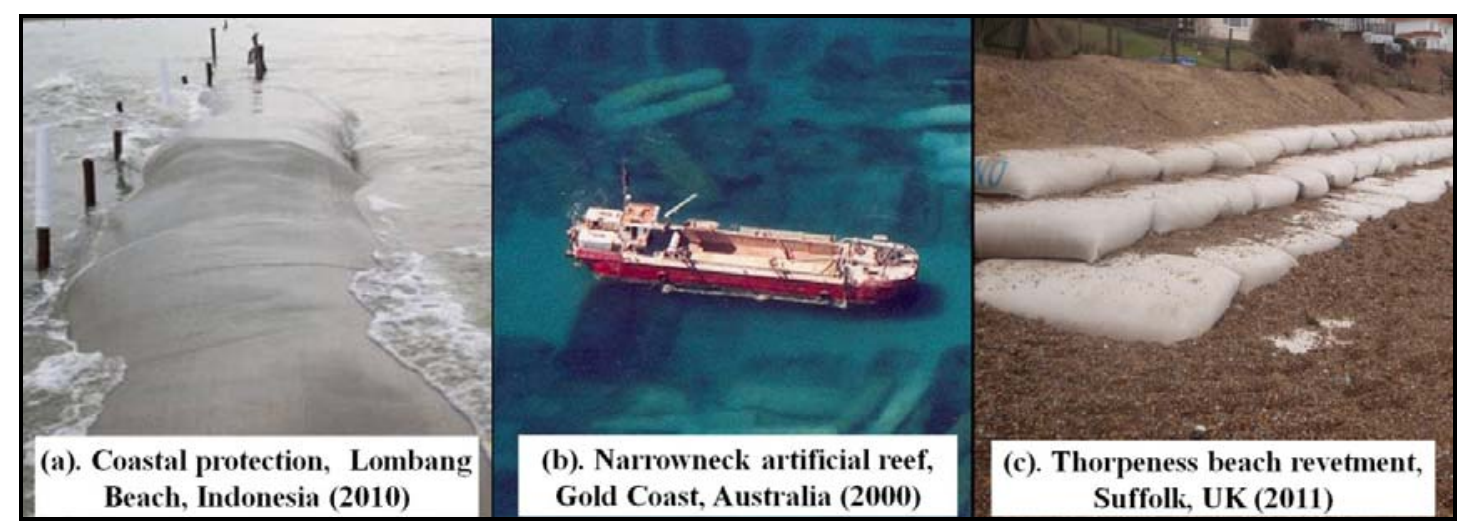

Figure 1: Coastal Structures Made of Geotextile Sand Containers (Photos Courtesy of NAUE)

The hydraulic processes affecting the stability of GSC-structures were extensively investigated (e.g. Oumeraci et al (2002b, 2003, 2007), Recio (2007)). Nevertheless, GSC is still an emerging technology and no proper guidelines are available for the design of GSC-structures on a sound

\footnotetext{
${ }^{1}$ Leichtweiss-Institute for Hydraulic Engineering and Water Resources, Technische Universitaet Braunschweig, Beethovenstr. 51a, 38106 Braunschweig, Germany
} 
scientific base (Dassanayake and Oumeraci, 2009b; Oumeraci and Recio, 2010). Due to the flexibility and the lower specific gravity of GSC as compared to rock or concrete armour units, GSCs behave differently and therefore, the established design formulae for rock or concrete units are not applicable.

\section{EXISTING HYDRAULIC STABILITY FORMULAE AND NOMOGRAMS}

Several authors suggested several formulae for the hydraulics stability of GSC-Structures. Among those works, contributions from Wouters (1998), Pilarczyk (2000), Oumeraci et al. (2002a, 2002b, 2002c, 2003, 2007), Recio (2007), Mori (2008), Recio and Oumeraci (2010), Coghlan et al. (2009), Hornsey et al. (2011) are noteworthy. The existing hydraulic stability formulae can be categorised into the following three groups:

Group 1: Early GSC-structures were designed using the hydraulic stability formula for stone armour layers such as Hudson's formula (1956). Only the weight of GSC was considered similar to any other conventional coastal structure.

Group 2: The Hudson formulae does not include the wave period and contains the empirical coefficients $k_{D}$ which is not appropriate for GSC structures as the response GSCs to wave loads basically differs from that of rigid armour units. Therefore, Wouters (1998) proposed a new stability formula (Eq. 1) for GSCs based on the Hudson's formula and the previous experimental data (e.g. Bouyze and Schram 1990). This new formula was developed explicitly for GSC structures by introducing a modified stability number (Ns) which accounts for the wave period through surf similarity parameter $\xi_{0}$, together with a new empirical coefficient $\mathrm{C}_{\mathrm{w}}$ as a more appropriate substitute for $\mathrm{k}_{\mathrm{d}}$ :

$$
N s=\frac{H s}{\left(\rho_{G S C} / \rho_{W}-1\right) \cdot D}=\frac{C_{W}}{\sqrt{\xi_{0}}} \text { with } \xi_{0}=\tan \alpha / \sqrt{\left(\mathrm{Hs} / \mathrm{L}_{0}\right)}
$$

Where; $\mathrm{N}_{\mathrm{s}}=$ stability number [-], Hs = incident significant wave height [m], $\rho_{\mathrm{W}}=$ density of water $[\mathrm{kg} / \mathrm{m} 3], \rho_{\mathrm{GSC}}=$ density of GSCs $[\mathrm{kg} / \mathrm{m} 3], \mathrm{C}_{\mathrm{w}}=$ empirical parameter derived from hydraulic stability tests [-], D = thickness of armour layer [m], $\alpha=$ slope angle of the GSC structure $\left[^{\circ}\right]$, $\mathrm{L}_{0}=\mathrm{g} \mathrm{T}^{2} /(2 \pi)=$ deep water wave length calculated using the mean wave period $[\mathrm{m}]$

More recently, Oumeraci et al. (2002a, 2002b, 2002c, 2003) proposed new formulae using the stability number proposed by Wouters (1998) and based on new small and large scale model tests. Since GSCs on the slope and on the crest of a coastal structure experience different wave loads and different boundary conditions that resulted in different stability behaviours, these new formulae separately consider the GSCs on the slope and the GSCS on the crest of the structure. This was the second main development as it was recognised crest and slope GSCs behave differently.

Group 3: The simple stability formulae of Group 2 were developed without considering explicitly the effect of deformation of GSCs. Though this effect is implicitly included to some extent in the empirical parameter $\mathrm{C}_{\mathrm{w}}$, it is necessary to understand the governing underlying failure mechanisms of GSCs which basically different from rigid armour units and to account for them in more process-based stability formulae. According to Oumeraci and Recio (2010), previous experimental studies have shown that the dislodgment and pullout of the slope containers by wave action, including the sliding and the overturning of crest containers are strongly affected by the deformation of the sand containers. Simple stability formulae mentioned above cannot explicitly account for the deformation and other mechanisms affecting the hydraulic stability. Since, GSCs are different from conventional structures in many ways, a different approach was required. One of the remarkable steps in this direction is the development of the first process-based hydraulic stability for GSC-structures by Recio (2007).

Due to the complexity of the hydraulic stability formulae by Recio et al. (2010), Hornsey et al. (2011), proposed different design nomograms for the hydraulic stability of GSC-structures (Table 1) However, GSC is still a developing technology and comprehensive design guidelines are not yet available. Certainly, the hydraulic stability of GSC is more complex as GSC-structures may experience a number of specific failure modes (Jackson et al., 2006, Deltares 2008, Lawson 2008, Oumeraci and Recio 2010). Most of these failure modes are influenced by the engineering properties of GSCs. This study discussed the significance of important engineering properties of GSCs and their influence on the hydraulic stability of GSC-structures. Based on a comprehensive literature survey and the analysis of previous model tests on the stability of GSC-revetments (Dassanayake and Oumeraci, 2009a), it was concluded that some new experiments were needed to: study the effects of engineering properties on the hydraulic stability of GSC-structures, obtain required parameters for modelling, clarify some 
processes, and validate a CFD-CSD model system for the hydraulic stability of GSCs which is in progress (Dassanayake and Oumeraci, 2012c).

\begin{tabular}{|c|c|c|}
\hline Authors/Structures & Formulae / Nomograms & Remarks \\
\hline $\begin{array}{l}\text { Hudson (1956)/ } \\
\text { Initially for rubble } \\
\text { mount structures } \\
\end{array}$ & $\begin{aligned} N_{S} & =\frac{H}{\Delta D_{n}}=\left(K_{D} \cot \alpha\right)^{1 / 3} \\
W_{50} & =\frac{\rho_{S} g H^{3}}{K_{D}\left(\rho_{S} / \rho_{W}-1\right)^{3} \cot \alpha}\end{aligned}$ & $\begin{array}{l}\text { Formula based on geometrical } \\
\text { considerations of the balance of wave } \\
\text { generated flow forces acting on an } \\
\text { armour stone in a slope of a } \\
\text { breakwater. Laternew } K_{D} \text { values were } \\
\text { found for different types of armour } \\
\text { units and structures }\end{array}$ \\
\hline $\begin{array}{l}\text { Wouters (1998)/ } \\
\text { GSC-revetments }\end{array}$ & $\begin{array}{c}N_{s}=\frac{H_{s}}{\left(\rho_{E} / \rho_{w}-1\right) \cdot D}=\frac{C_{w}}{\sqrt{\xi_{0}}} \\
D=l \cdot \sin \alpha \\
l c=\frac{H_{s} \sqrt{\xi_{0}}}{\left(\rho_{E} / \rho_{w}-1\right) \cdot \sin \alpha C_{w}}\end{array}$ & $\begin{array}{l}\text { a formula for describing the stability } \\
\text { number with the surf similarity } \\
\text { parameter based on previous } \\
\text { experimental data. Instead of the } \\
\text { required weight of the armour unit, the } \\
\text { thickness } D \text { of the cover layer defined } \\
\text { by the relationship } D=\text { lc sina }\end{array}$ \\
\hline $\begin{array}{l}\text { Oumeracietal. } \\
(2002 \mathrm{~b}, 2002 \mathrm{c}, \\
2003) / \\
\text { GSC-revetments } \\
\text { and low crested } \\
\text { structures }\end{array}$ & $\begin{array}{c}N_{\text {s,slope }}=\frac{H_{S}}{\left(\rho_{E} / \rho_{w}-1\right) \cdot D}<\frac{C_{w}}{\sqrt{\xi_{0}}} \\
l c=\frac{H_{s}^{3 / 4} \sqrt{T}}{C_{w}\left(\frac{2 \pi}{g}\right)\left(\frac{\rho_{G S C}}{\rho_{w}}-1\right) \sqrt{\frac{\sin (2 \alpha)}{2}}} \\
N_{s, \text { crest }}=\frac{H_{s}}{\left(\rho_{G S C} / \rho_{w}-1\right) \cdot D}<0.79+0.09 \frac{R_{c}}{H_{s}} \\
I c=\frac{H_{s}}{\left(\frac{\rho_{G S C}}{\rho_{w}}-1\right)\left(0.79+0.09 \frac{R_{c}}{H_{s}}\right) \sin (\alpha)}\end{array}$ & $\begin{array}{l}\text { Based on the Hudson (1956) formula } \\
\text { for the hydraulic stability of rock armour } \\
\text { units (non-deformable) and similarly to } \\
\text { Wouters (1998), a stability number } \\
\text { Ns is formulated and postulated to be a } \\
\text { function of the surf similarity. Two } \\
\text { different formulae for slope and crest } \\
\text { GSCs for high overtopping revetments } \\
\text { and low-crested structures based on } \\
\text { small and large scale experiments } \\
\text { Here } D=\text { Ic sina }\end{array}$ \\
\hline $\begin{array}{l}\text { Recio (2007) and } \\
\text { Recio and Oumeraci } \\
(2010) / \\
\text { GSC-revetments } \\
\text { and submerged } \\
\text { GSC-structures } \\
\end{array}$ & $\begin{array}{c}l_{c(\text { sliding })} \geq u^{2} \frac{\left[0.5 K S_{C D} C_{D}+2.5 K S_{C L} C_{L} \mu\right]}{\left[\mu K S_{R} \Delta g-K S_{C M} C_{M} \frac{\partial u}{\partial t}\right]} \\
l_{c \text { (overturning) }} \geq u^{2} \frac{\left[0.05 K O_{C D} C_{D}+1.25 K O_{C L} C_{L}\right]}{\left[0.5 \Delta K O_{R} g-0.1 K O_{C M} C_{M} \frac{\partial u}{\partial t}\right]}\end{array}$ & $\begin{array}{l}\text { Process based stability formulae for } \\
\text { different types of GSC-structures } \\
\text { considering two key hydraulic failure } \\
\text { modes: overturning and sliding. Force } \\
\text { coefficients were found by conducting } \\
\text { several small scale experiments. }\end{array}$ \\
\hline $\begin{array}{l}\text { Mori (2008) and } \\
\text { Moriet al. (2008)/ } \\
\text { Submerged GSC- } \\
\text { breakwaters } \\
\end{array}$ & $N_{s}=\frac{H_{s}}{\left(\rho_{E} / \rho_{w}-1\right) \cdot D}<\frac{C_{w}}{\sqrt{\xi_{0}}}$ & $\begin{array}{l}\text { Showed the applicability of Oumeraciet } \\
\text { al (2003) to estimate the stability of } \\
\text { crest GSCs of submerged GSC- } \\
\text { structures studied using experiments }\end{array}$ \\
\hline $\begin{array}{l}\text { Recio et al. (2010)/ } \\
\text { Submerged GSC- } \\
\text { reefs }\end{array}$ & $\begin{array}{l}\text { Stability nomograms to be Used for Feasibility } \\
\text { Studies based on Recio (2007) }\end{array}$ & $\begin{array}{l}\text { Discuss the extension of the Recio } \\
\text { (2007) formulae to design prototype } \\
\text { structures and provides nomograms for } \\
\text { different GSC applications }\end{array}$ \\
\hline $\begin{array}{l}\text { Coghlan et al. } \\
\text { (2009) and Hornsey } \\
\text { et al. (2011)/ } \\
\text { Non-overtopping } \\
\text { GSC revetments }\end{array}$ & $\begin{array}{l}\text { Stability nomograms were developed for two } \\
\text { specific GSC geometries by using the data from } \\
\text { all tests, }\end{array}$ & $\begin{array}{l}\text { Nomograms indicate the design wave } \\
\text { height at the structure to be used for an } \\
\text { "Initial Damage" criterion for structure } \\
\text { slope and TP. }\end{array}$ \\
\hline \multicolumn{3}{|c|}{$\begin{array}{l}C_{D}, C_{L} C_{M}=\text { drag, lift and inertia coefficients } \\
C_{w}=\text { empirical parameter derived from } N_{S}[-] \\
D_{50}=\text { thickness of armour layer }[\mathrm{m}] \\
g=\text { acceleration due to gravity } \\
\mathrm{H}_{\mathrm{S}}=\text { incident significantwave height }[\mathrm{m}] \\
K_{D}=\text { stability coefficient (obtained experimentally) } \\
\mathrm{KO}=\text { coef. account for deformation during overturning } \\
\mathrm{KS}=\text { coef. account for deformation during sliding } \\
\mathrm{L}_{0}=\mathrm{g} \mathrm{T}^{2} /(2 \pi)=\text { deep water wave length using } \mathrm{T}_{\mathrm{p}}[\mathrm{m}] \\
\mathrm{Ic}_{\mathrm{c}}=\text { length of the container [m] } \\
N_{s}=\text { stability number }[-] \\
\mathrm{Rc}=\text { crest freeboard }[\mathrm{m}]\end{array}$} \\
\hline
\end{tabular}




\section{ENGINEERING PROPERTIES OF GEOTEXTILE SAND CONTAINERS}

The most important engineering properties of GSCs are the mechanical properties of the geotextile material (e.g. friction, tensile strength, etc.), the sand fill ratio, type of the fill material and the interface friction, in fact most of these properties will affect the deformation of GSCs and the movement of sand inside the container. More importantly, these properties are interrelated. The importance of these aspects has been highlighted by many authors worldwide. However, the knowledge about the relative contributions of the effect of the properties of GSC on the hydraulic stability of GSC-structures is still very poor. Moreover, the effect of these and further properties on the durability of the GSCs structure is also still very poor (Wiśniewski et al., 2012).

\section{Sand Fill Ratio}

The sand fill ratio of GSCs was identified as an important parameter for the hydraulic stability of GSC-structures (e.g. Venis 1967, Grüne 2006, Oumeraci et al. 2007, Oumeraci and Recio 2010, Wilms et al. 2011). It affects the deformability of containers, the internal movement of sand, and the resistance against sliding, which directly affect the hydraulic stability of a GSC-structure. Oumeraci et al. (2007) have performed a systematic study to determine the optimum fill ratio for the GSC used for scour protection of offshore monopiles subject to storm waves in the large wave flume (GWK), Hannover, Germany. According to their findings, the stability increases with increasing sand fill ratio. A similar behaviour of GSCs was reported by Wilms et al. (2011) based on another series of large scale experiments in GWK. Therefore, not only the weight of the container but also the fill ratio significantly influences the hydraulic stability of a sand container lying on the seabed.

Therefore, Oumeraci and Recio (2010) recommended more systematic research to investigate the influence of the sand fill ratio on the mechanisms responsible for the hydraulic failure of GSC. Moreover, the sand fill ratio considerably influences the long term performance of GSC-structures. Hence, the future research should be essentially directed towards the definition of an optimal sand fill ratio by accounting for the deformation properties of the geotextile and by balancing the advantages and drawbacks of high and moderate sand fill ratios. Ultimately, due to its considerable effect on the hydraulic stability and the long term performance, future standards and guidelines should explicitly address the issue of the sand fill ratio of GSC (Oumeraci and Recio, 2010, Wiśniewski et al., 2012)

Even though the sand fill ratio is found to be a key factor governing the hydraulic stability of GSCs, none of the exiting stability formulae for the design of GSC-structures accounts for the sand fill ratio. Moreover, existing definitions for the sand fill ratio are very vague and not sufficiently practical to be implemented in the engineering practice. In order to overcome the drawbacks of existing definitions of the sand fill ratio, a new definition is developed based on the initial volume of an inflated geotextile bag and dry bulk density of sand. The shape of the geotextile bag is initially flat and twodimensional. Once it is filled, it becomes a three dimensional pillow. That final shape of the filled GSC has a complicated geometry which is difficult to idealize by a simple shape. Therefore, the calculation of the maximum volume of a geotextile container fully filled with sand is challenging (Fig. 2).

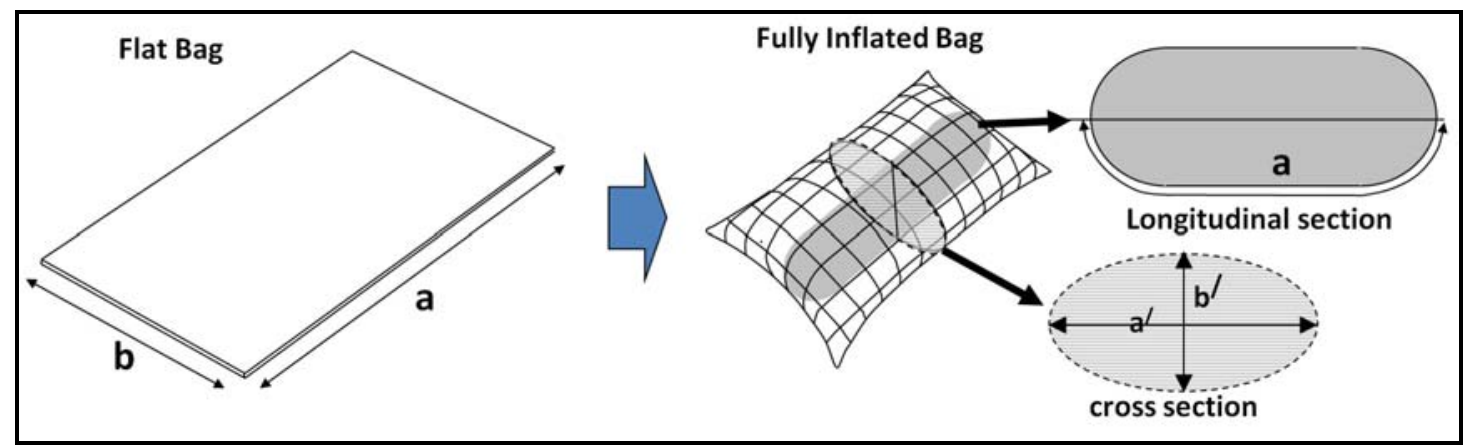

Figure 2. Calculation of initial theoretical volume of a GSC

According to Robin (2004), when the dimensions of a flat rectangular bag, which can neither stretch nor shear, with dimensions $a, b$, bounds for the maximum volume $\left(V_{\max }\right)$ of a closed bag obtained by fully inflating the bag is approximately given by;

$$
V_{\max }=a^{3}\left[\frac{b}{\pi a}-0.142\left(1-10^{-b / a}\right)\right]
$$


In this paper, the sand fill ratio was calculated based on the theoretical maximum volume estimated using the formula of Robin (2004). The dry bulk density of sand $(1480 \mathrm{~kg} / \mathrm{m} 3)$ was used to calculate the required mass of the sand to achieve a desired sand fill ratio. During the small scale model experiments, it was found that the $0.5 \mathrm{~m}$ long model GSCs can be filled up to $120 \%$ of this initial theoretical maximum volume as a result of the elongation of geotextile material, even if the GSCs are filled carefully to avoid excessive elongations.

\section{Friction between GSCs}

"Pullout" mechanisms of GSCs have been observed not only during laboratory tests (Oumeraci, 2003, Recio ,2007), but also in the real life projects (Jackson, 2006). Recio (2007) attempted to experimentally and numerically investigate the process of pulling out containers from a GSCrevetment due to wave attack and concluded that the interface friction between GSCs considerably affects the hydraulic stability of GSC-Structures. Though the formulae suggested by Recio (2007) already account for the interface friction between GSCs, the effect of interface friction properties is still not fully clarified or/and experimentally verified.

Interface friction mainly depends on: friction properties of geotextile material (both short term and long term), contact area between two containers, the overlapping length (seaward slope), the sand fill ratio (shape of the GSCs), the type of fill material, etc. Until recent past, the test results obtained by means of direct shear stress tests were the only available data to assess the friction between GSCs. In the recent past, few studies have been carried out in order to understand the interface shear strength of a pile of sand bags (Krahn et al. 2007, Matsushima et al. 2008). Krahn et al. (2007) conducted large scale interface shear testing of sand bags and other dike materials. Also Matsushima et al. (2008) carried out full-scale loading tests with soil bags. These works provide more insight into interface shear properties of geotextile sand/soil containers. The most promising finding of the research study of Krahn et al. (2007) is that the interface shear strength between sand filled bags is greater than that of the geotextile material alone. Furthermore, those studies show that the estimations of interface friction between sand bags using direct shear tests with geotextile samples are not accurate enough dilatant

Behavior of Sandbags. Therefore, more investigations should be conducted to understand the friction between GSCs and its effect on the hydraulic stability of GSC-Structures.

\section{EXPERIMENTAL INVESTIGATIONS}

Based on a comprehensive literature survey (Dassanayaken and Oumeraci, 2009a) and the analysis of previous model tests on the stability of GSC-revetments (e.g. Recio, 2007), it was decided that some new experiments are needed to study the influence of the engineering properties of GSCs on the hydraulic stability of GSC-structures and to obtain the required parameters for modelling, to clarify some processes and to validate the numerical models, which are being performed. The influences of the sand fill ratio, the friction between GSC (by varying the type of geotextile material) and some geometrical parameters such as the stacking method (tandem or staggered) on the hydraulic stability were studied through two types of model tests; pullout tests and wave flume tests.

\section{Underwater Pullout tests}

The main objective of the pullout tests was to study the factors influencing the pullout forces of submerged GSCs. The wave tests (Fig. 3 \& Fig. 4) were then conducted in the $2 \mathrm{~m}$ wide LWI-wave flume to investigate the effect of the aforementioned engineering properties on the processes that govern the hydraulic stability. However, it is not possible to design a small scale model that accurately simulates all of the important engineering properties of GSCs simultaneously. Therefore, relatively thin geotextile materials were selected for the small scale model tests (Table 2). This selection was based on both the analysis of expert opinions from the industry and on a comparative analysis of the properties of geotextile materials available in the market. Model GSCs were filled with washed sand $\left(\mathrm{D}_{50}=0.25 \mathrm{~mm}\right)$ with no fine materials below $0.10 \mathrm{~mm}$.

Pullout tests were conducted to quantify the effect of the sand fill ratio, the type of geotextile material, interface friction, seaward slope of GSC-structures (overlapping length), stacking pattern, etc. on the underwater pullout forces. From the five different tested sand fill ratios $(80 \%, 90 \%, 100 \%$, $110 \%$, and $120 \%$ ) in 48 different testing scenarios it was observed that the pullout forces increase with increasing sand fill ratios (i.e. with increasing weight of the GSCs). In order to determine the optimum sand fill ratio, a nondimensional parameter was introduced as a relative pullout force. The results show that sand fill ratios of $90 \% \sim 100 \%$ need a higher relative pullout force than for other sand fill ratios. 
Therefore, fill ratios between $90 \% \sim 100 \%$ are found to be optimal in terms of the resistance against pullout.

Two different types of geotextile, a woven and a nonwoven material (Table 2), were used for the construction of model GSCs. These two materials show a clear difference in their pullout resistance which is roughly proportional to the friction coefficients. A comparison of the response of slope GSCs and that of crest GSCs shows that the slope containers have at least 130\% higher (average value for the 2nd layer from the top) resistance than crest GSCs. Furthermore, all GSCs show 30\% 50\% higher pullout resistances than what was estimated based only on the friction properties of geotextile materials. Key results of the pullout tests are discussed in Dassanayake and Oumeraci (2012a and 2012b) which will contribute to further optimisation of GSC-structures.

\section{Hydraulic stability tests in the wave flume}

Wave tests (Fig.s 3 and 4) were conducted in the $2 \mathrm{~m}$ wide LWI-wave flume to investigate the effect of the above mentioned engineering properties on the processes that govern the hydraulic stability. Approximately 350 model tests were performed by varying the wave parameters over a wide range as well as the engineering, geometrical parameters and properties of the GSCs such as geometry, the sand fill ratio, the type of geotextile material, etc. In the model tests, incident and transmitted wave parameters, the behaviour of the structure (high speed video records), the flow velocity around the structure, and the pressure variations at the crest of the GSCs structure were systematically recorded.

Fig. 3 shows the model setup and instrumentation of the hydraulic stability tests in the $2 \mathrm{~m}$ wide wave flume, which is $90 \mathrm{~m}$ long, and $1.25 \mathrm{~m}$ deep. A total of 20 wave gauges including 3 arrays were used for wave measurements. The wave gauge arrays in front of the structure were used for the wave reflection analysis, while the gauge array behind the structure was used to determine wave transmission. The structure was also instrumented with a pressure gauge on its seaward face to record wave-induced pressure on the front face of the structure and two ADV-probes (Acoustic Doppler Velocimeters) to measure the flow velocity around the structure. The sloping part of the cross-shore profile $(\sim 1: 25)$, built at a distance of $23.025 \mathrm{~m}$ from the wave maker, represents a foreshore slope and transitions into a horizontal platform of height $0.415 \mathrm{~m}$ on which the GSC structure is located.

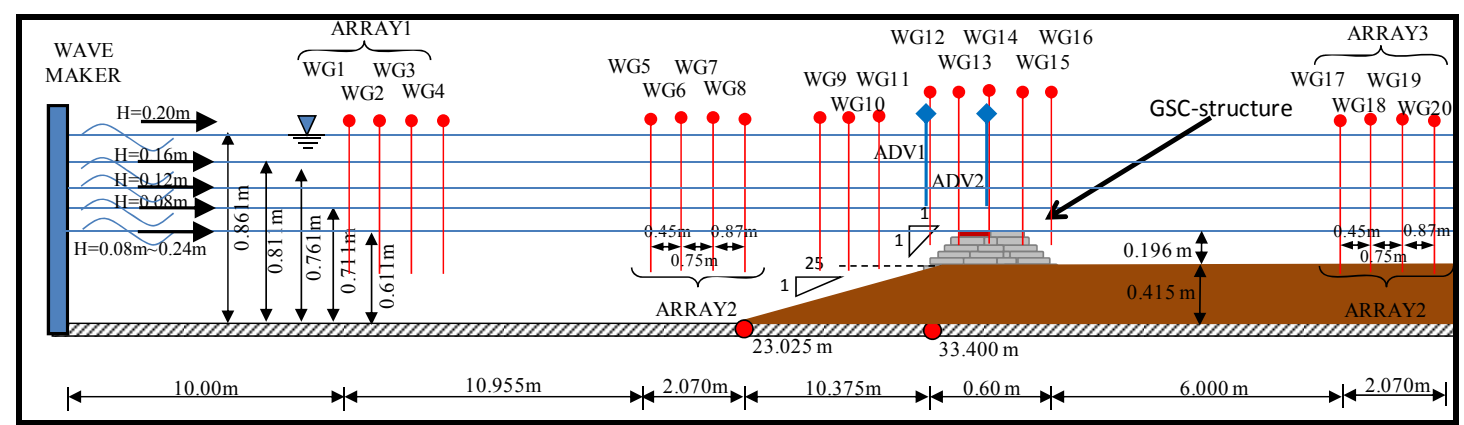

Figure 3: Model setup - hydraulic stability tests in the $2 \mathrm{~m}$ wide wave flume of LWI

\begin{tabular}{|c|c|c|c|c|}
\hline & & $\begin{array}{l}\text { Nonwoven } \\
\text { geotextile }\end{array}$ & $\begin{array}{c}\text { Woven } \\
\text { geotextile }\end{array}$ & \\
\hline Description & Unit & Value & Value & Test Procedure \\
\hline Mass per Area & $\mathrm{g} / \mathrm{m}^{2}$ & 200 & 110 & DIN EN 9864 \\
\hline Thickness & $\mathrm{mm}$ & 1.2 & $<0.1$ & DIN EN 9863-1 \\
\hline Tensile strength $\left(\mathrm{md} / \mathrm{cmd}^{\star}\right)$ & $\mathrm{kN} / \mathrm{m}$ & $7.5 / 12.0$ & $18.0 / 18.0$ & DIN EN ISO 10319 \\
\hline $\begin{array}{l}\text { Elongation at max tensile strength } \\
\left(\mathrm{md} / \mathrm{cmd}^{\star}\right)\end{array}$ & $\%$ & $50 / 30$ & $20 / 10$ & DIN EN ISO 10319 \\
\hline Characteristic Opening Size & $\mathrm{mm}$ & 0.08 & $\mathrm{n} / \mathrm{a}$ & DIN EN ISO 12956 \\
\hline Permeability $\mathrm{VI}_{\mathrm{H} 50}$ Index & $\mathrm{m} / \mathrm{s}$ & $6.0 \times 10^{-2}$ & $\mathrm{n} / \mathrm{a}$ & DIN EN ISO 11058 \\
\hline Permeability Flow rate $_{H 50}$ & $1 / \mathrm{sm}^{2}$ & 60 & $\mathrm{n} / \mathrm{a}$ & DIN EN ISO 11058 \\
\hline $\begin{array}{l}\text { Interface friction angle } \\
\text { Static friction } \\
\text { Kinetic friction }\end{array}$ & $\begin{array}{l}\text { deg. } \\
\text { deg. }\end{array}$ & $\begin{array}{l}22.62^{\circ} \\
14.88^{\circ}\end{array}$ & $\begin{array}{l}13.33^{\circ} \\
12.23^{\circ}\end{array}$ & $\begin{array}{l}\text { underwater friction } \\
\text { properties using } \\
\text { direct shear tests }\end{array}$ \\
\hline
\end{tabular}




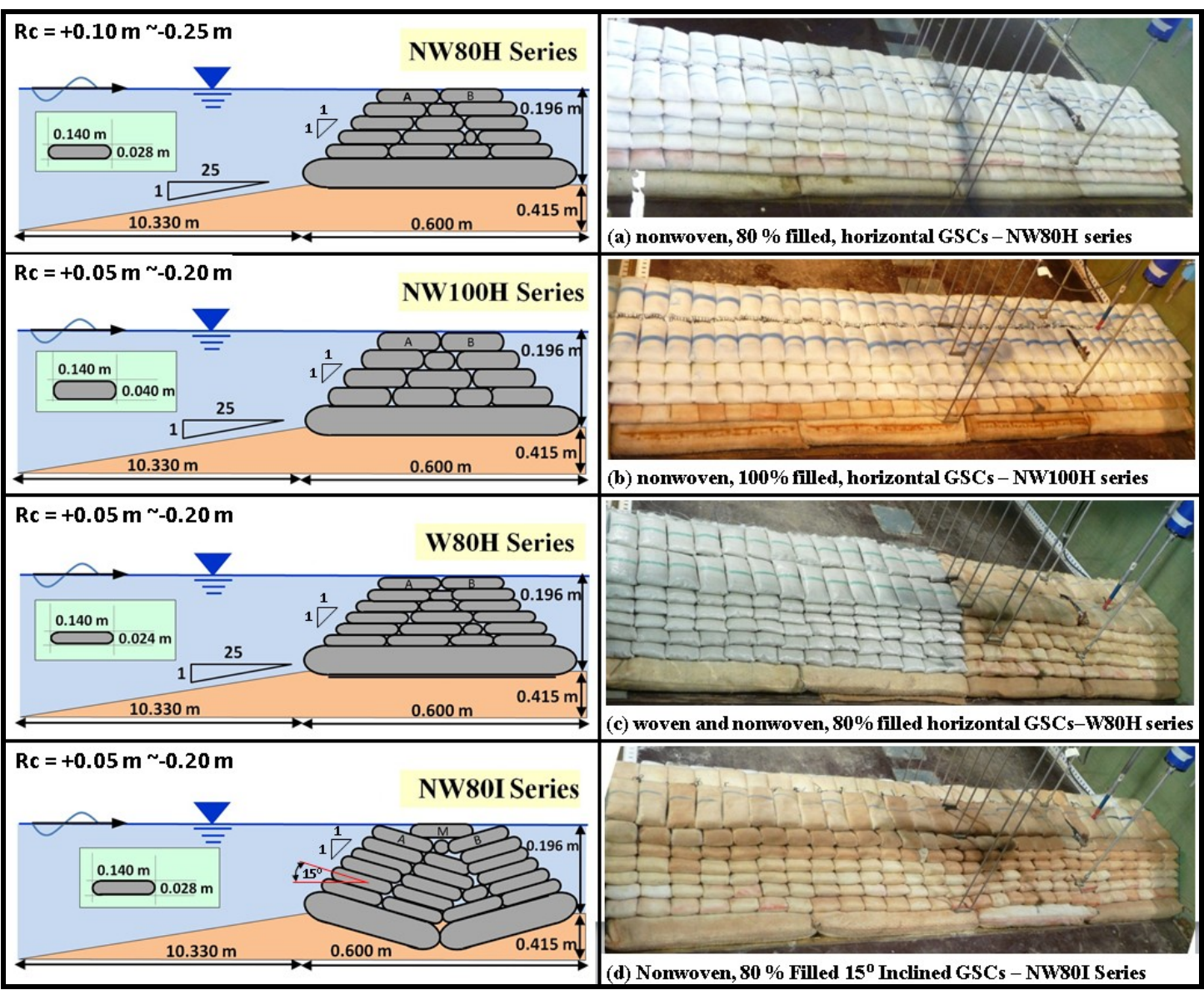

Figure 4: Model configurations and test series: (a) nonwoven, $80 \%$ filled, horizontal GSCs; (b) nonwoven, $100 \%$ filled, horizontal GSCs, (c) woven and nonwoven, $80 \%$ filled horizontal GSC, (d) nonwoven, $80 \%$ filled, 15 inclined GSCs;

Table 3: New damage classification for individual GSCs and for GSC-structures as whole (modified from Dassanayake et al. 2011)

\begin{tabular}{|l|l|}
\hline $\begin{array}{l}\text { Damage Classification I (single GSC): } \\
\text { considering only a single GSC in the most vulnerable position (critical GSCs) }\end{array}$ \\
\hline "Stable" & Horizontal displacement $<10 \%$ of GSC length (or width) / Upwand rotation < 10" \\
\hline "Movement" & $\begin{array}{l}10 \% \text { of GSC length, width }<\text { Horizontal displacement }<50 \% \text { of GSC length (or width) } \\
10^{\circ}<\text { Upward rotation }<45^{\circ}\end{array}$ \\
\hline "Detachment" & $\begin{array}{l}\text { Horizontal displacement }>50 \% \text { of GSC length, width } \\
\text { Upward rotation }>45^{\circ}\end{array}$ \\
\hline \hline
\end{tabular}

\section{Damage Classification II (GSC-structure): considering all critical GSC layers of a GSC-Structure ${ }^{++}$}

\begin{tabular}{|c|c|c|c|c|}
\hline $\begin{array}{c}\text { No Damage } \\
{[\text { DC 0] }}\end{array}$ & $\begin{array}{c}\text { Incipient Motion } \\
\text { [DC 1] }\end{array}$ & $\begin{array}{c}\text { Minor Damage } \\
\text { [DC 2] }\end{array}$ & $\begin{array}{c}\text { Medium Damage } \\
\text { [DC 3] }\end{array}$ & $\begin{array}{l}\text { Total Failure } \\
\text { [DC 4] }\end{array}$ \\
\hline $\begin{array}{c}<10 \text { \% of critical GSCS } \\
\text { mowed } \\
\text { Wo critical GSCs detached }\end{array}$ & $\begin{array}{c}10 \% \approx 50 \% \text { of critical } \\
\text { GSCs moved } \\
<5 \% \text { of critical GSCs } \\
\text { detached }\end{array}$ & $\begin{array}{c}>50 \% \text { of critical GSCS } \\
\text { mowed } \\
5 \% \sim 20 \% \text { of critical GSCS } \\
\text { detached }\end{array}$ & $\begin{array}{l}20 \% \sim 40 \% \text { of critical } \\
65 C \text { detached }\end{array}$ & $\begin{array}{c}>40 \% \text { of citical GSCS } \\
\text { detached }\end{array}$ \\
\hline
\end{tabular}

${ }^{++}$level of damage to GSC-structures, after 100 regular waves during regular wave tests or 1000 waves with JONSWAP spectrums during irregular wave tests

Since the existing damage classification for conventional coastal structures (e.g. rubble mound breakwaters) is not applicable to GSC-structures, a new method of damage classification is introduced for this study (Table 3). If a GSC is displaced less than $10 \%$ of its length or shows an angular motion less than $10^{\circ}$, then it is considered as "stable". If a GSC shows a greater displacement than $10 \%$ of its 
length or greater angular motions than $10^{\circ}$ it is considered either as an "incipient motion" or a "displacement" depending on the magnitude as shown in Table 3. By considering the critical GSClayers of a GSC-structure the level of damage was then classified into five categories from "no damage" (DC0) to "total failure" (DC4).

\section{SELECTED RESULTS}

\section{Effect of crest freeboard on the hydraulic stability of GSC-structures}

According to Oumeraci et al. (2003), the hydraulic stability of crest GSCs depends primarily on the relative freeboard $\mathrm{R}_{\mathrm{C}} *=\mathrm{R}_{\mathrm{C}} / \mathrm{Hs}$ whereas the hydraulic stability of slope GSCs depends primarily on the surf similarity parameter. However, the data from the current experimental results show that even the crest GSCs of submerged and low crest structures are strongly dependent on both the freeboard and the surf similarity parameter. Therefore, hydraulic stability curves for different crest freeboards were developed based on one damage category 1; "Incipient motion" (DC 1) as mentioned in Table 3.

Ideally, a single hydraulic stability curve should be found which can describe the behaviour of submerged/low crested GSC-structures with different positive and negative crest freeboards. Vidal et al. (1992) showed a relationship with the relative freeboard and the stability number $\left(\mathrm{R}_{\mathrm{C}} *=\mathrm{Hs} / \mathrm{D}_{50}\right)$ of low crested rubble mound breakwaters by considering four different damage categories. The possibility of developing a similar relationship for the submerged/low crested GSC structures was also examined in the current research study. Based on the above mentioned new damage classification (Table 3), new non-dimensional hydraulic stability curves were developed (e.g. Fig. 5). Furthermore, different regions were demarcated in order to assess the expected damages to GSC-structures, when design wave conditions are exceeded.

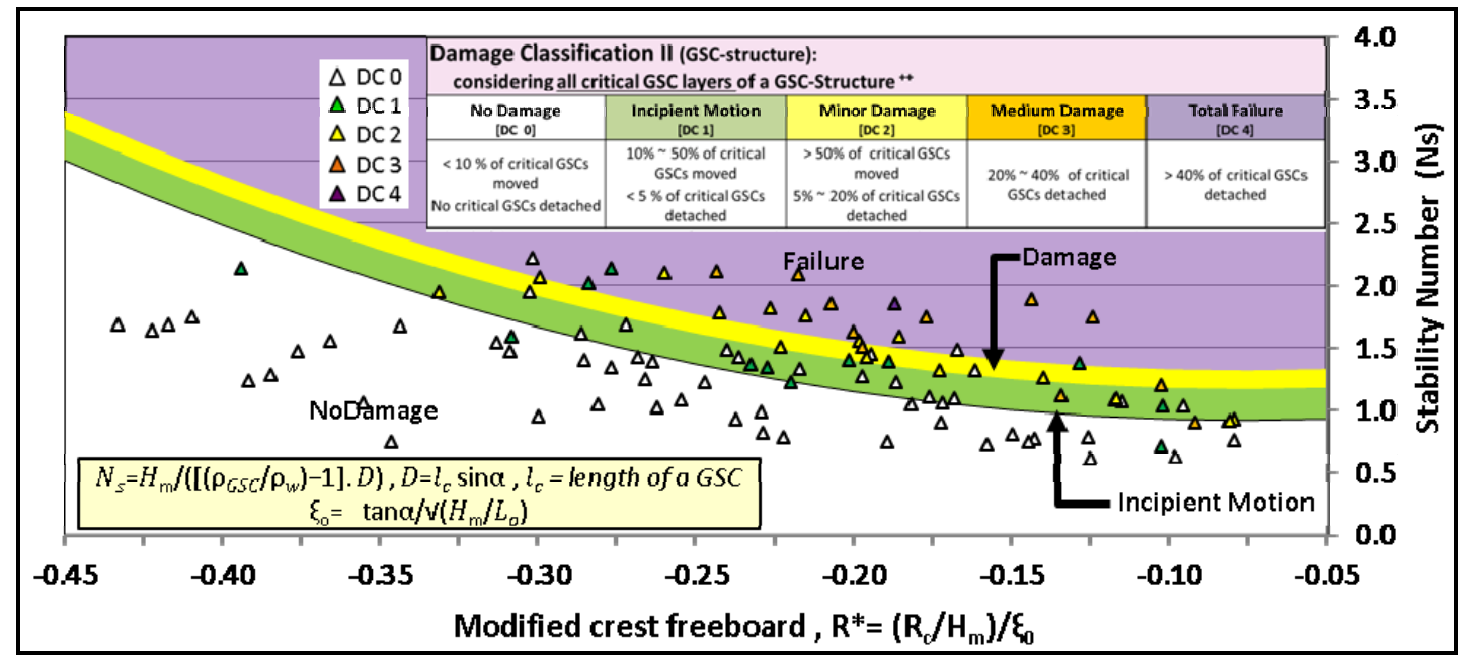

Figure 5. New hydraulic stability curves for a submerged structure made of nonwoven, $80 \%$ filled GSC (series: $\mathrm{NW8OH} / \mathrm{Rc}<0$ )

For the quantification of the effect of the sand fill ratio and the type of geotextile material on the hydraulic stability, test results of different test series were compared by considering nonwoven $80 \%$ filled GSCs (series: NW80H / Rc =0) as the basis (Fig. 6). For each test scenario, "incipient motion" curves were plotted (damage category DC 1), as described in Table 3. 


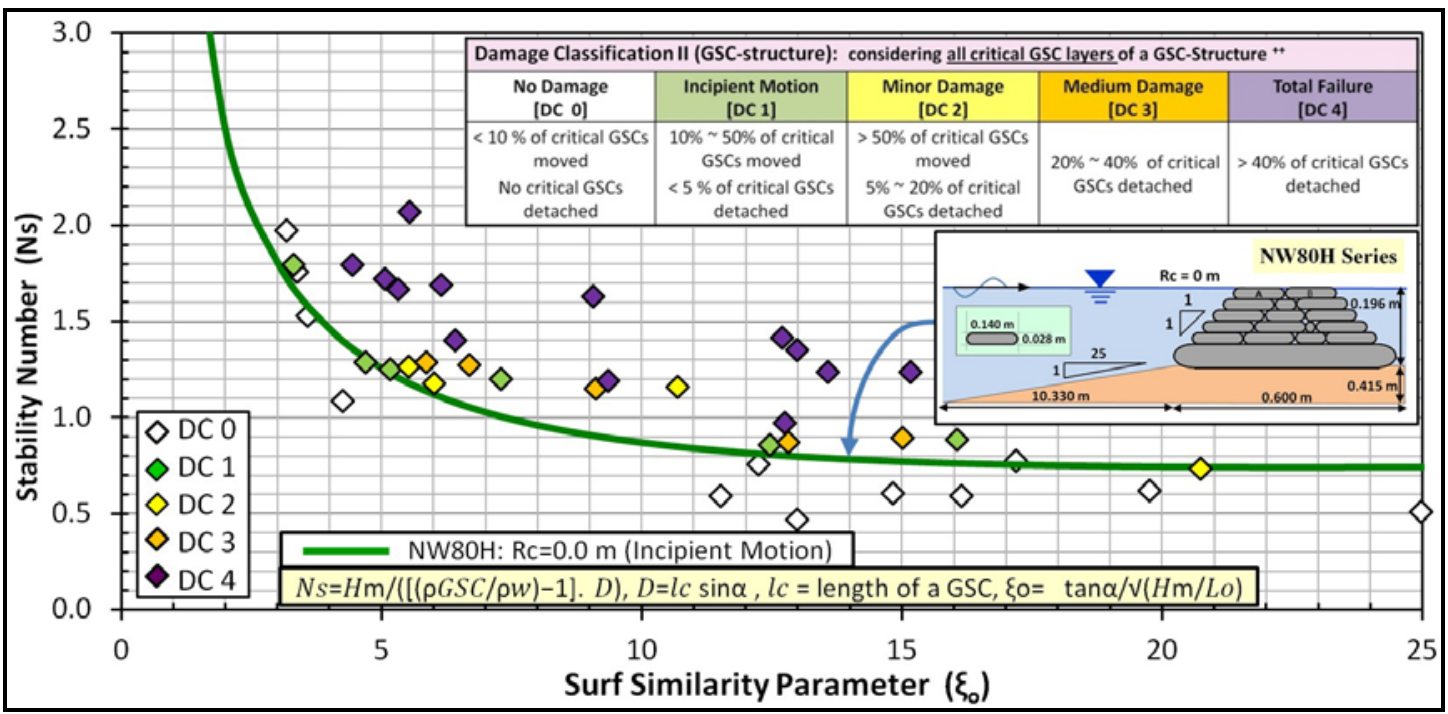

Figure 6: Hydraulic stability curve for low crested GSC-structures made of nonwoven, $80 \%$ filled GSCs (series $\mathrm{NW80H/Rc}=0 \mathrm{~m}$ )

\section{Effect of sand fill ratio on the hydraulic stability of GSC-structures}

In Fig. 7 the "incipient motion" (damage category DC 1) curves for $80 \%$ and $100 \%$ filled GSCs are comparatively shown (series $\mathrm{NW} 80 \mathrm{H}$ and $\mathrm{NW} 100 \mathrm{H}$ ). For the tested conditions it can clearly be seen that $100 \%$ filled GSCs are more stable than $80 \%$ filled GSCs. The $100 \%$ filled GSCs show incipient motions only when the stability number is increased by $36 \%$ as compared to the $80 \%$ filled GSCs. Though the overlapping length and contact area between GSCs were less for the $100 \%$ fill ratio, the $100 \%$ filled containers were more stable. This might be due to the higher weight and possible higher permeability of the GSC-structure associated with a $100 \%$ sand fill ratio as compared to those with an $80 \%$ sand fill ratio.

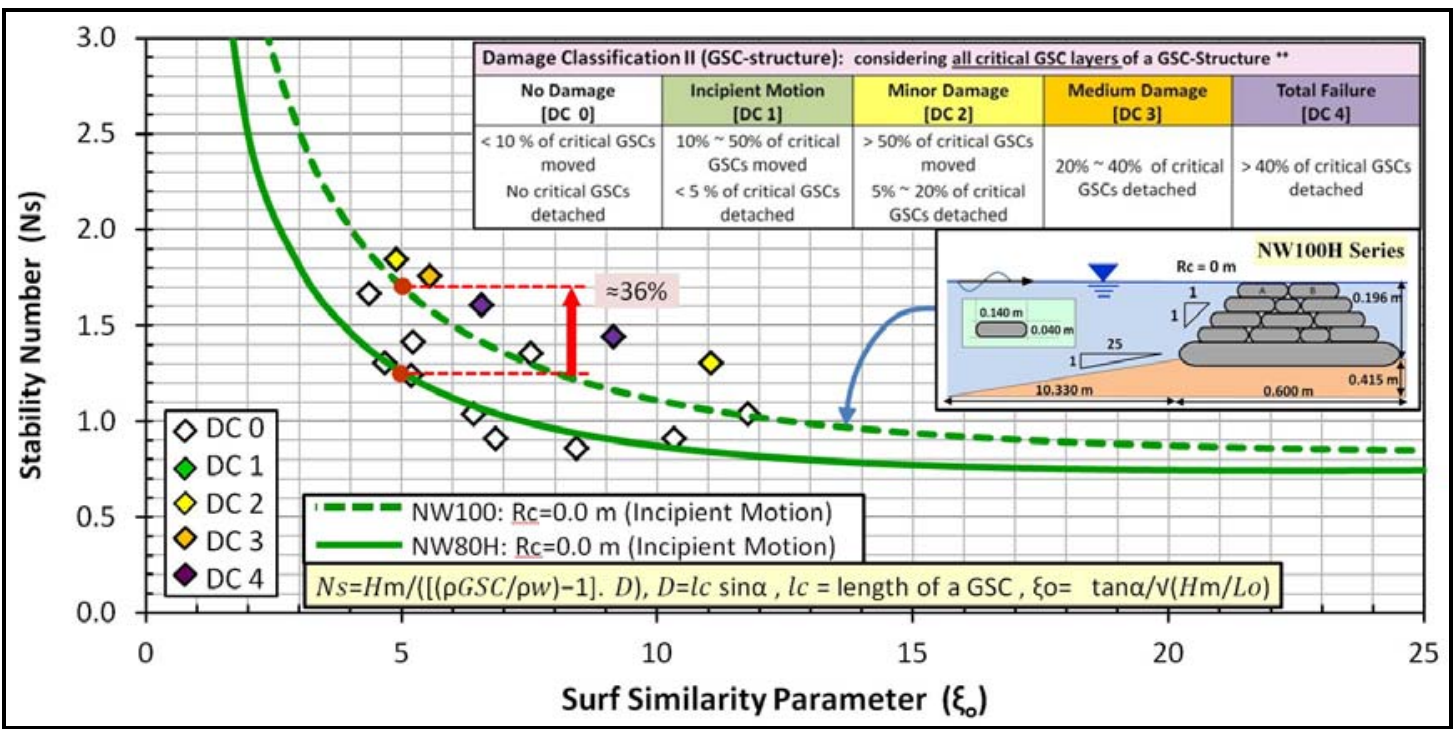

Figure 7: Effect of sand fill ratio on the hydraulic stability of low crested GSC-structures: comparison of $\mathbf{8 0} \%$ and $100 \%$ filled GSCs made of nonwoven geotextile (NW80H; Rc $=0 \mathrm{~m}$ and $\mathrm{NW} 100 \mathrm{H} ; \mathrm{Rc}=0 \mathrm{~m}$ )

Effect of the type of geotextile material on the hydraulic stability of GSC-structures

The effects of the type of geotextile material used for the construction of GSC on the hydraulic stability of the GSC-structure were studied by using a nonwoven (series: NW80H) and a woven (series: NW80H) material (Fig. 8). Both types of GSCs were filled $80 \%$ and had approximately the same weights under buoyancy. During the tests series, when Rc=0 m, the stability numbers of 
nonwoven GSCs were almost twice as those of woven GSCs for "incipient motion" cases (damage category; DC 1).

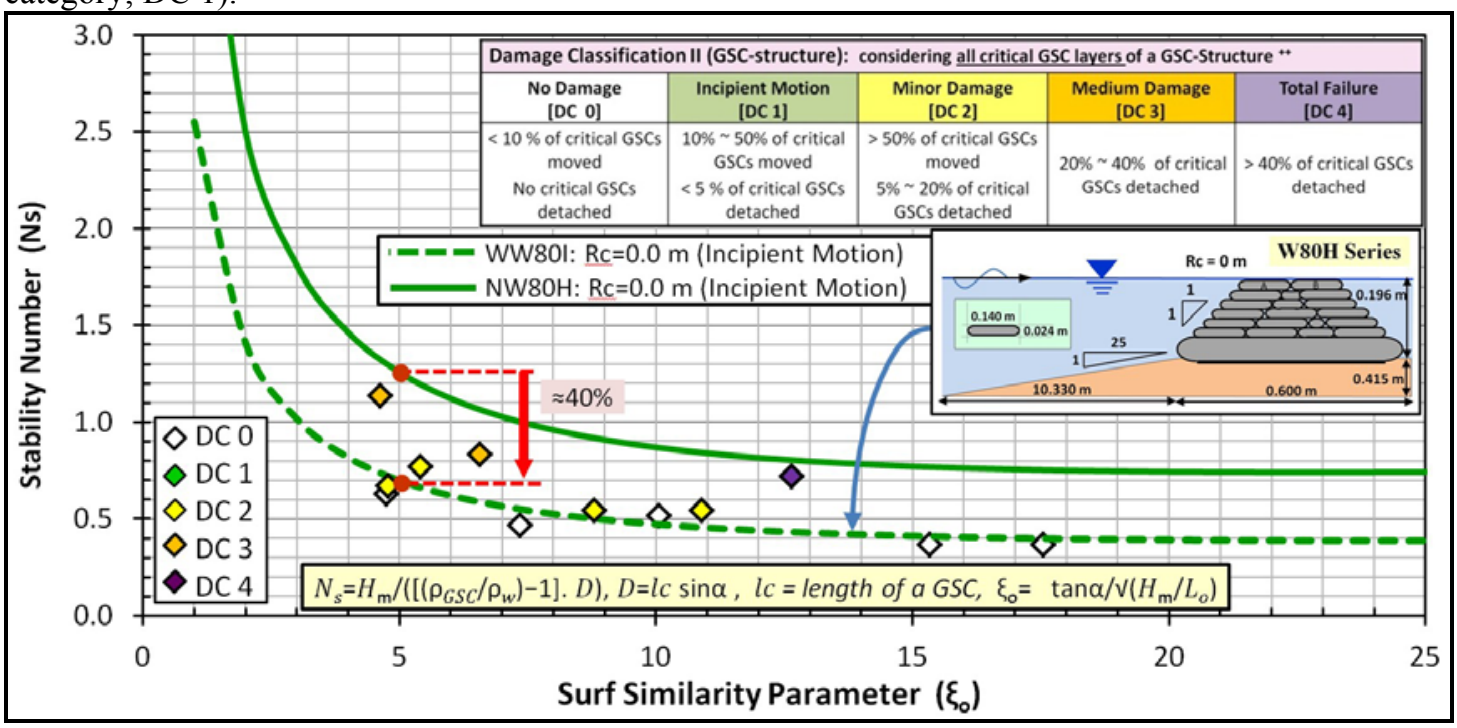

Figure8: Effect of the type of geotextile on the hydraulic stability of low crested GSC-structures: comparison of nonwoven (interface friction angle 22.64) and woven (interface friction angle 13.33) geotextile

As the submergence depth increases, the differences between woven and nonwoven GSCs are reduced in terms of hydraulic stability, mainly because of different dominant failure mechanisms. When the submergence depth is small, both woven and nonwoven GSC-structures failed due to sliding caused by overtopping waves, whereas for relatively larger submergence depths, overturning and "uplift and drift" were commonly observed. For overturning and "uplift and drift" failure mechanisms, the effect of friction between GSCs is expectedly insignificant.

Though the wave conditions that trigger the incipient motions of submerged woven and nonwoven GSCs are relatively similar, the damage progression occurred more rapidly in woven structures compared to nonwoven structures. For selected comparable tests, progressive damage analysis was performed considering the number of waves, the type of failure mode, and the number of detached GSCs (see Dassanayake and Oumeraci 2012b). Due to high friction properties, nonwoven GSCs are detached mainly due to overturning. However, in several other cases, "uplifting and drifting" were also noticed. In contrast, woven GSCs failed mainly due to sliding, which requires relatively less effort. Consequently, the damage progression of woven GSC-structure was much more rapid compared to nonwoven GSC-structures. Therefore, not only the conditions required to start damage to a GSCstructure, but also the development of the damage is important for a comprehensive quantification of the effect of the interface friction between GSCs on the hydraulic stability.

\section{Effect of inclination angle on the hydraulic stability of GSC-structures}

The influence of the inclination angle of GSCs (between the longitudinal axis of GSCs and the horizontal plane) on the hydraulic stability was studied by comparing the stability of horizontally placed and angularly placed GSCs. Fig. 9 shows a comparison of the "incipient motion" (Damage category; DC1) curves for two test series $\mathrm{NW} 80 \mathrm{H}$ (inclination angle $=0$ ) and NW80I (inclination angle $=15^{\circ}$. When $\mathrm{Rc}=0 \mathrm{~m}$, inclined GSC showed more stability to wave attack than horizontal GSC. For example, when the surf similarity parameter is 5 , the stability number is increased by $30 \%$ as compared to the horizontally placed GSCs.

Furthermore, the inclined placement of GSCs increases the hydraulic stability by restricting the internal movement of sand inside GSCs. Recio and Oumeraci (2009) described thoroughly the process governing the internal movement of sand. This sand movement causes deformation of GSCs and ultimately a significant reduction in hydraulic stability against sliding. When GSCs are placed with an inclination angle rather than the conventional horizontal placement, gravitation force will prevent the movement of sand towards the seaward edge of GSCs and thereby increase the long-term stability of GSC-structures. 
However, when the submergence depth was $0.20 \mathrm{~m}$, there is no considerable difference between the wave conditions required for the initiation of damage to inclined GSC-structure in comparison to the horizontally placed GSCs. The progressive damage analysis of horizontally and inclined GSCs subject to regular waves showed that inclined GSC have higher resistance against wave attack as the progression of damage in the NW80I test is considerably slower than the NW80H test (Dassanayake and Oumeraci 2012b).

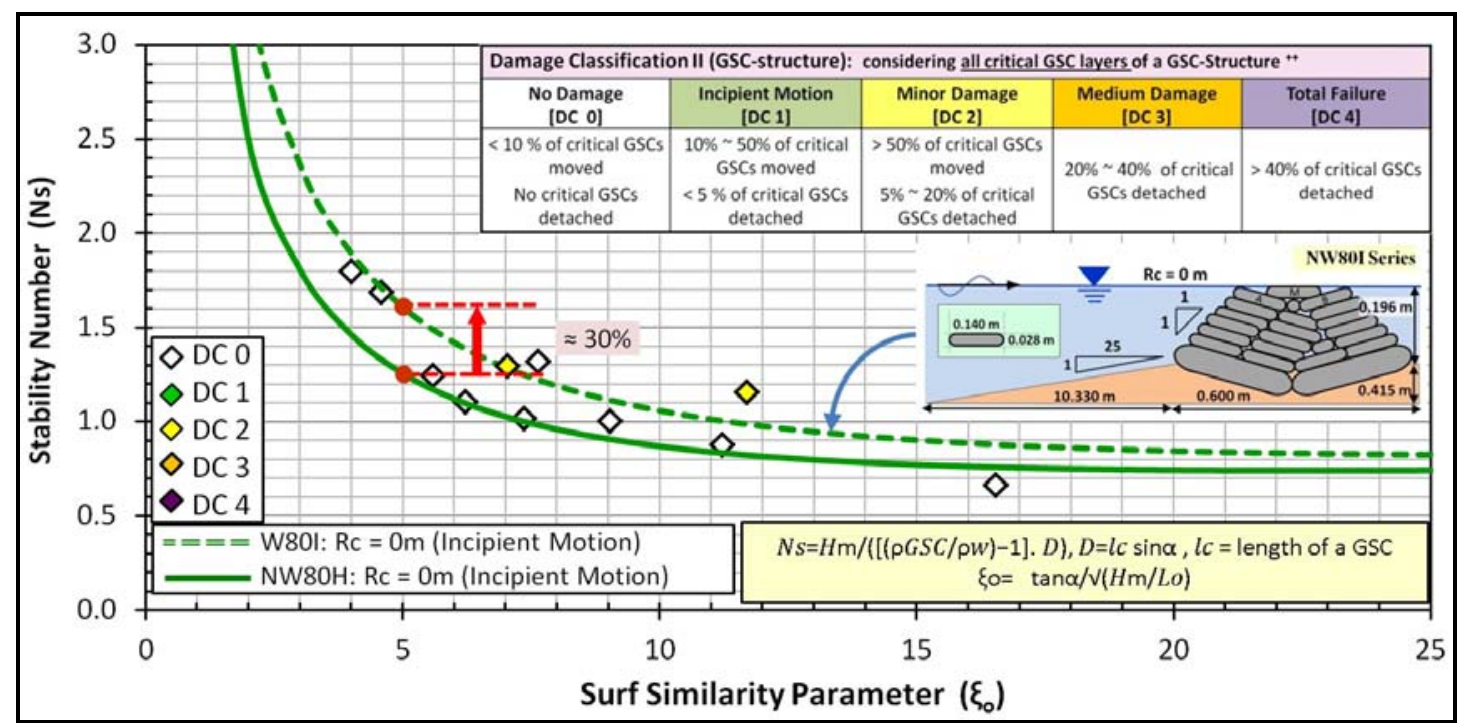

Figure 9: Effect of the inclination angle of GSCs on the hydraulic stability of low crested GSC-structures: a comparison of horizontal and 15 inclined GSCs for Rc $=0 \mathrm{~m}$

\section{SUMMMARY, CONCLUDING REMARKS AND OUTLOOK}

\section{Summary and concluding remarks}

The sand fill ratio, the type of geotextile material and the interface friction between GSCs affect different processes governing the hydraulic stability of GSC-structures. This $\mathrm{PhD}$ research study represents the first attempt worldwide to systematically quantify the effects of the engineering properties and the inclined placement of GSCs on the hydraulic stability.

First, pullout tests were conducted to quantify the effect of the sand fill ratio, the type of geotextile material, seaward slope of GSC-structures (overlapping length), and stacking pattern on underwater pullout forces. From the five different tested sand fill ratios $(80 \%, 90 \%, 100 \%, 110 \%$, and $120 \%)$, the pullout forces increase when the sand fill ratios (or increment of the weight of GSC) are increased. In order to determine the optimum sand fill ratio, a non-dimensional parameter was introduced as a relative pullout force. The sand fill ratios between $90 \% \sim 100 \%$ were then found to be optimal in terms of the resistance against pullout of the GSCs. In this comparative analysis only the amount of sand filled into the GSCs was varied and the size of the empty bag was unchanged (same amount of geotextile). Hence, the weight of each unit grows as the sand fill ratio increases. Furthermore, all the GSCs show a 30\% 50\% higher pullout resistance than what was estimated based solely on the interface friction properties of geotextile materials without the sand fill. These results are expected to substantially contribute to further optimisation of GSC-structures.

Second, wave flume tests were conducted on low crested GSC-structures with both positive and negative crest freeboards. GSCs show different failure mechanisms for different submergence depths and the importance of engineering properties of GSCs also varies depending on the dominant failure mechanism for a particular GSC-structure and for a particular freeboard. As expected, for most of the low crested structures, the crest GSCs represent the critical elements. The hydraulic stability of these crest GSCs is a function of both the relative freeboard and the surf similarity parameter. For the tested conditions with a zero freeboard, GSCs made of woven geotextile (with an approximately 50\% lower friction coefficient than nonwoven geotextile) resulted in $40 \%$ lower stability numbers, when the incipient motions of crest GSCs are considered.

Though most of the existing studies (e.g. PIANC 2011) on the construction of GSC-structures recommend a sand fill ratio of $80 \%$ for GSC, $100 \%$ filled GSC show a $36 \%$ higher stability number when the surf similarly parameter is 5 , compared to $80 \%$ filled GSC. Therefore, future research and 
design guidance should address the definition of an optimal sand fill ratio by accounting for the elongation properties of the geotextile and by balancing the advantages and drawbacks of high and moderate sand fill ratios.

Apart from changing the engineering properties of GSC, the hydraulic stability can be increased by changing the inclination angle of GSC in the construction process. An inclination angle of only $15^{\circ}$ resulted in approximately $30 \%$ higher stability number compared to horizontally placed GSCs, when the wave conditions required for incipient motion of the GSCs are considered.

In addition to the improvements of the hydraulic stability which are achieved by a higher friction angle between GSCs, higher sand fill ratios and inclined placement of GSCs, these parameters significantly retard the damage development of GSC-structures over the entire storm duration. Therefore, not only the conditions required to trigger damage to a GSC-structure, but also the development of the damage and the different damage levels that might result, are important for the comprehensive quantification of the effect of the different factors considered in this study. For conventional rubble mound structures studies are available on the prediction of the damage for a series of storms throughout the lifetime of the structure. This allows engineers to balance initial costs with expected maintenance costs in order to reduce the overall costs of the structure and to reduce possibility of unexpected maintenance costs (Melby, 2005). Since GSC structures are highly sensitive to the changes in wave parameters, it is essential to know the damage development to practically achieve optimal GSC-structures by selecting proper engineering properties of GSCs and the most appropriate inclination angle of GSCs. This series of experiments has highlighted the influences of engineering properties and of the inclined placement of GSCs on both temporal and spatial damage development. In addition, the awareness of dominant failure modes will help to create site specific GSC solutions by altering the most relevant engineering properties of GSCs.

\section{Outlook}

The results of these experiments will be used for the validation of the numerical modelling system (combined CFD and CSD models) for the hydraulic stability GSC-structures which is in progress at LWI. After validation, the numerical model will be used for a more detailed parameter study. The available process-based stability formulae (e.g. Recio, 2007) will then be refined and simplified to be more user-friendly by combining both experimental and numerical modelling results. In addition, new simplified Hudson like hydraulic stability formulae (see Oumeraci et al, 2003) and an operational computational tool for the design of GSC-structures will be developed.

Since the sand fill ratio, the interface friction between GSCs, and the inclination angle of GSCs considerably influence the hydraulic stability and the long term performance of GSC-structures, the future research should essentially address these parameters. Ultimately, future standards and guidelines should explicitly address the aforementioned parameters of GSCs as well as the durability and life time issues as suggested by Oumeraci and Recio, 2010 and Wiśniewski et al, 2012).

\section{ACKNOWLEDGMENTS}

The PhD fellowship granted for the first author by the German Academic Exchange Service (DAAD) is greatly acknowledged. Leichtweiss Institute, Technische Universität Braunschweig, Germany, and NAUE GmbH \& Co. KG are gratefully acknowledged for their financial support to conduct the laboratory investigations.

\section{REFERENCES}

Bleck, M., Werth, K. 2012. Geotextile sand filled containers as structures against erosion of sandy coasts a comparison to rock material relating design, functionality, eco-effectiveness and costs, $12^{\text {th }}$ Baltic Sea Geotechnical Conference, Rostock, Germany

Bouyze, J.G., Schram, A.R. 1990, Stabiliteit van Grondkribben en Onderwatergolbrekers Opgebouwd uit Zandworsten, TU-Delft, Studentarbeit (Master Student Project Report) (in Dutch).

Carley, J.T., Coghlan, I.R., Blacka, M.J., Cox, R.J., Hornsey, W. 2011, Performance of sand filled geotextile container (Geocontainer) structures in North Queensland during tropical cyclone Yasi, Coasts and Ports 2011 : Diverse and Developing: Proceedings of the $20^{\text {th }}$ Australasian Coastal and Ocean Engineering Conference and the $13^{\text {th }}$ Australasian Port and Harbour Conference, Engineers Australia, 2011: 134-139

Coghlan, I.R., Carley, J.T., Cox, R.J., Blacka, M.J., Mariani, A., Restall, S., Hornsey, W., Sheldrick, S. 2009. Two-dimensional physical modelling of sand filled Geocontainers for coastal protection, 
Proceedings of Australasian Coasts and Ports Conference 2009, New Zealand Coastal Society, Wellington, NZ.

Dassanayake, D.T. and Oumeraci, H. 2009a. Experimental and numerical modelling of the hydraulic stability of geotextile sand containers for coastal protection - State of the art report, Internal report, Leichtweiß-Institute for Hydraulic Engineering and Water Resources, Braunschweig, Germany.

Dassanayake, D.T., Oumeraci, H. 2009b. Planned research on the hydraulic stability of geotextile sand containers, 7. FZK-Kolloquium, „Potenziale für die Maritime Wirtschaft“, Hannover, Germany.

Dassanayake, D.T., Soysa, A., Munith-Hadi, F., Oumeraci, H. 2011. Hydraulic stability of low-crested GSC-structures, Internal report, Leichtweiß-Institute for Hydraulic Engineering and Water Resources, Braunschweig, Germany.

Dassanayake, D.T., Oumeraci, H. 2012a. Important engineering properties of geotextile sand containers and their effect on the hydraulic stability of GSC-structures, Terra et Aqua Journal, Issue 127, International Association of Dredging Companies, The Netherlands, 3-11.

Dassanayake, D.T., Oumeraci, H. 2012b. Engineering properties of geotextile sand containers and their effect on hydraulic stability and damage development of low-crested / submerged structures, The International Journal of Ocean and Climate Systems, Vol. 3, Issue 3, Multi Science Publishing, Essex, UK, 135-150

Dassanayake, D.T., Oumeraci, H. 2012c. Numerical modelling of the hydraulics stability of GSCs with COBRAS-UC and UDEC 5, Internal report, Leichtweiß-Institute for Hydraulic Engineering and Water Resources, Braunschweig, Germany.

Deltrares, 2008. Large scale physical model test on the stability of geocontainers, by Van Steeg, P and Klein Breteler, M., Deltares report prepared for Delft cluster

Grüne, J., Sparboom, U., Schmidt-Koppenhagen, R., Wang, Z., Oumeraci, H. 2006. Large-scale investigations of geotextile sand containers used for scour protection of offshore monopiles supporting wind energy turbines, Proceedings of OMAE2006 : 25 $5^{\text {th }}$ International Conference on Offshore Mechanics and Arctic Engineering, Hamburg, Germany

Heerten, G., Jackson, A., Restall, S., Saathoff, F. 2000. New developments with mega sand containers of nonwoven needle-puncture geotextile for the construction of coastal structures, Proceedings of $27^{\text {th }}$ International Conference on Coastal Engineering, Sydney, Australia

Hornsey, W.P. Carley, J.T., Coghlan, I.R., Cox, R.J. 2011. Geotextile sand container shoreline protection systems: Design and application, Journal of. Geotextiles and Geomembranes 29, 425439

Hudson, R. 1956. Laboratory investigation of rubble-mound breakwaters. Journal of the Waterways and Harbour Division, 93-118.

Krahn, T., Blatz, J., Alfaro, M., Bathurst, R. J. 2007. Large-scale interface shear testing of sand bag dyke materials. Geosynthetics International, 14, No. 2, 119-126.

Jackson, L.A., Corbett, B.A., Restall, S.J. 2006), Failure modes and stability modelling for design of sand filled geosynthetic units in coastal structures, Proceedings of $30^{\text {th }}$ International Conference on Coastal Engineering, World Scientific, San Diego, USA, Book of Abstracts.

Lawson, C.R. 2008. Geotextile containment for hydraulic and environmental engineering, Geosynthetics International, 15, No. 6, 384-427

Lenze, B., Heerten, G., Saathoff, F., Stelljes, K. 2002, Geotextile sand containers - Successful solutions against beach erosion at sandy coasts and scour problems under hydrodynamic loads, Littoral 2002, The Changing Coast. EUROCOAST / EUCC, Porto, Portugal.

Matsushima, K., Aqil, U., Mohri, Y., Tatsuoka, F. 2008. Shear strength and deformation characteristics of geosynthetic soil bags stacked horizontal and inclined, Geosynthetics International, 15, No. 2, 119-135.

Melby, J. A. 2005. Damage development on stone-armored breakwaters and revetments, ERDC/CHL CHETN-III-64, US Army Corps of Engineers, USA.

Mori, E., D'eliso, C., Aminti, P.L. 2008. Physical modelling on geotextile sand container used for submerged breakwater, Proceedings of $2^{\text {nd }}$ international conference on the application of physical modelling to port and coastal protection, Coastlab08, Bari, Italy

Mori, E. 2009), Coastal structures made of geotextile elements filled with sand: field and experimental research, $P h D$ Thesis, Università degli Studi di Firenze, Florence, Italy

Oumeraci, H., Bleck, M. , Hinz, M. 2002a. Untersuchungen zur Funktionalität geotextiler Sandcontainer. Leichweiss-Institute for Hydraulic Engineering and Water Resources, Report Nr. 874, Braunschweig, Germany, (in German). 
Oumeraci, H., Bleck, M., Hinz, M. , Kübler, S. 2002b. Großmaßstäbliche Untersuchungen zur hydraulischen Stabilität geotextiler Sandcontainer unter Wellenbelastung. Leichweiss-Institute for Hydraulic Engineering and Water Resources, Report Nr. 878, Braunschweig, Germany, (in German).

Oumeraci, H., Bleck, M., Hinz, M. , Möller, J., 2002c. Theoretische Untersuchungen zur Anwendung geotextiler Sandcontainer im Küstenschutz. Leichweiss-Institute for Hydraulic Engineering and Water Resources, Report Nr. 866, Braunschweig, Germany, (in German).

Oumeraci, H., Hinz, M., Bleck, M., Kortenhaus, A. 2003. Sand-filled geotextile containers for shore protection, COPEDEC VI, Colombo, Sri Lanka.

Oumeraci, H., Grüne, J., Sparboom, U., Schmidt-Koppenhagen, R., Wang, Z., 2007. Untersuchungen zur Kolkbildung und zum Kolkschutz bei Monopile-Gründungen von OffshoreWindenergieanlagen), Final research report, Coastal Research Centre (FZK), (in German)

Oumeraci, H., Recio, J. 2010, Geotextile Sand Containers for shore protection, Invited Chapter in Handbook of Coastal and Ocean Engineering, World Scientific Publishing, Singapore, 553-600.

PIANC, 2011. The Application of geosynthetics in waterfront areas-PIANC Report No. 113 by MarCom Working Group 113.

Pilarczyk, K. W. 2000. Geosynthetics and geosystems in hydraulic and coastal engineering. A.A. Balkema, Rotterdam, the Netherlands.

Recio, J. 2007. Hydraulic stability of geotextile sand containers for coastal structures- effect of deformations and stability formulae, $P h D$ Thesis, Leichweiss-Institute for Hydraulic Engineering and Water Resources, Braunschweig, Germany.

Recio, J., Oumeraci, H., 2009. Processes affecting the hydraulic stability of coastal revetments made of geotextile sand containers. Coastal Engineering 56 (3), 260-284.

Recio, J., Oumeraci, H., Mocke, G., 2010. Stability formula and numerical model for structures made with geotextile sand containers used for coastal stabilization, 2nd International Conference on Coastal Zone Engineering and Management (Arabian Coast 2010), Muscat, Oman

Restall, S., Hornsey, W., Oumeraci, H., Hinz, M., Saathoff, F., Werth, K., 2004. Australian \& German experiences with geotextile containers for coastal protection, Proceedings of Eurogeo 3, Munich, Germany, $141-146$.

Restall, S.J., Jackson, L.A., Heerten, G., Hornsey, W.P., 2002. Case studies showing the growth and development of geotextile sand containers: an Australian perspective, Geotextiles and Geomembranes, Vol. 20, 321-342.

Robin, A.C. 2004, Paper bag problem, Mathematics Today, Bulletin of the Institute of Mathematics and its Applications, 40 (June 2004), 104-107.

Saathoff, J., Oumeraci, H., Restall, S., 2007. Australian and German experiences on the use of geotextile containers, Geotextiles and Geomembranes Journal, Vol. 25 ), Elsevier, 251-263.

Venis, W.A., 1968 , Closure of estuarine channels in tidal regions, Behaviour of dumping material when exposed to currents and wave action, De ingenieur, 50, 1968

Vidal, C., Losada, M.A., Medina, R., Mansard, E.P.D., Gomez-Pina, G., 1992. A universal analysis for the stability of both low-crested and submerged breakwaters. Proceedings of $23^{\text {rd }}$ International Conference on Coastal Engineering, ASCE, 1679-1692.

Wilms, M., Wahrmund, H., Stahlmann, A., Heitz, C., Schlurmann, S. 2011. Kolkbildung und dimensionierung des Kolkschutzsystems eines OWEA Schwerkraftfundaments, Hydraulische dodellversuche zum STRABAG Schwerkraftfundament, HTG Kongress 2011, Germany, 395-404.

Wishaw, D., Gibbs, D., Hornsey, W., 2011. Durability of geosynthetic sand containers subject to extreme Australian weather conditions, Coasts and Ports 2011 : Diverse and Developing: Proceedings of the $20^{\text {th }}$ Australasian Coastal and Ocean Engineering Conference and the $13^{\text {th }}$ Australasian Port and Harbour Conference, Engineers Australia, 2011: 803-808.

Wouters, J. 1998. Open Taludbekledingen; Stabiliteit van Geosystems, Deftt Hydraulics Report H1930, Delft, The Netherlands.

Werth, K., Wilms, M., Peters, K., Stahlmann, A., Schlurmann, T., 2012. Offshore wind turbine foundations - hydrodynamic investigations, design, installation and durability of scour protection systems made of geotextile sand-filled containers, $12^{\text {th }}$ Baltic Sea Geotechnical Conference, Rostock, Germany, 310-316

Wiśniewski T., Oumeraci H. , Werth K, (2012): Geotextile sand containers in coastal engineering Factors affecting durability, degradation mechanisms, and lifetime prediction methods .Proceedings EuroGeo5, Valencia/Spain 